\title{
"Estimation of fintech market in Ukraine in terms of global development of financial and banking systems"
}

\begin{tabular}{ll} 
AUTHORS & $\begin{array}{l}\text { Józef Antoni Haber (D https://orcid.org/0000-0002-4913-5534 } \\
\text { Iryna D'yakonova } \\
\text { Ann Milchakova }\end{array}$ \\
\hline JRTICLE INFO & $\begin{array}{l}\text { Józef Antoni Haber, Iryna D'yakonova and Ann Milchakova (2018). Estimation of } \\
\text { fintech market in Ukraine in terms of global development of financial and banking } \\
\text { systems. Public and Municipal Finance, 7(2), 14-23. } \\
\text { doi:10.21511/pmf.07(2).2018.02 }\end{array}$ \\
\hline DOI & http://dx.doi.org/10.21511/pmf.07(2).2018.02 \\
\hline RELEASED ON & Monday, 24 September 2018 \\
\hline RECEIVED ON & Friday, 27 April 2018 \\
\hline ACCEPTED ON & Wednesday, 29 August 2018 \\
\hline LICENSE & $\begin{array}{l}(c) \text { Er } \\
\text { This work is licensed under a Creative Commons Attribution } 4.0 \text { International }\end{array}$ \\
\hline JOURNAL & License \\
\hline ISSN PRINT & "Public and Municipal Finance" \\
\hline ISSN ONLINE & $2222-1867$ \\
\hline PUBLISHER & $2222-1875$ \\
\hline FOUNDER & LLC “Consulting Publishing Company “Business Perspectives" \\
\hline & LLC “Consulting Publishing Company “Business Perspectives" \\
\hline
\end{tabular}

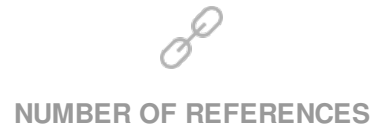

15

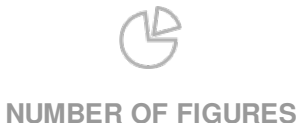

0

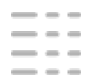

NUMBER OF TABLES

0

(C) The author(s) 2022. This publication is an open access article. 


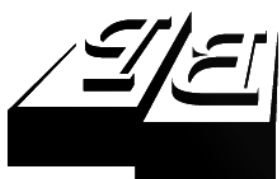

BUSINESS PERSPECTIVES

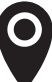

LLC "CPC "Business Perspectives" Hryhorii Skovoroda lane, 10, Sumy, 40022, Ukraine

www.businessperspectives.org
Received on: $27^{\text {th }}$ of April, 2018 Accepted on: 29th of August, 2018
(C) Jozef A. Haber, Iryna D’yakonova, Ann Milchakova, 2018

Jozef A. Haber, Professor, Doctor of Economic Sciences, WSB Universitie in Posnan faculty in Chorzów, Poland.

Iryna D'yakonova, Professor, Doctor of Economic Sciences, Education and Research Institute for Business Technologies "UAB" of Sumy State University, Ukraine.

Ann Milchakova, Ph.D. Student, Education and Research Institute for Business Technologies "UAB" of Sumy State University, Ukraine.
ESTIMATION OF FINTECH MARKET IN UKRAINE IN TERMS OF GLOBAL DEVELOPMENT OF FINANCIAL AND BANKING SYSTEMS

\begin{abstract}
This paper examines the fintech concept and fintech market structure. The theoretical and methodological approaches to the adaptation of the Ukrainian banking market to fintech in terms of globalization are investigated. The problems of Ukrainian banking system reforming after the national economy long-term recession are determined. Phases of technology development in the Ukrainian banking system are considered and fintech innovations in Ukraine are discovered.
\end{abstract}

Keywords

fintech market, globalization, financial systems, banking system

JEL Classification G21, E40, F50, L25, O33

\section{INTRODUCTION}

Nowadays the world faces the stage of global transformations that cover various spheres of people's social and economic development in different countries. The consequences of this process affect the structure of financial systems of different levels, as evidenced by crisis develops ments, emergence of systemic risks and increase of social tension in society. All these destructive factors have a negative impact on the country's economic stability and well-being level of its population.

The banking sector is most prone to transformational changes and impact of external and internal shocks. Therefore, at the present stage of development, the banking sector undergoes significant structural shifts and changes in approaches to the organization of their business processes. Customers' expectations, technological changes, regulatory requirements, crises in the real economy create an imperative of transformation in the banking system. Considering these factor, traditional banking institutions should support the development of fintech in their own interests.

\section{THEORETICAL BASIS}

Issues of innovation in the banking sector, the study of adaptation processes as a method of strategic planning and management of the bank are considered and covered in the writings of modern scholars and researchers. But despite the depth and serious level of processing of these problems, the findings require further analysis and development, since there is a lack of ordering of the conceptual construct 
in the works, the features of the banking system of Ukraine of the modern period are not fully reflected.

The term "fintech" is used in various business contexts, often inconsistent and ambiguous. For a long time, there were no attempts to find out the consensual meaning of this notion.

According to professor Schueffel (2016), "Fintech is a new financial industry that applies technology to improve financial activities". In its turn, the most authoritative source of British English language, Oxford Dictionary, determines fintech as "computer programs and other technologies used to support or activate banking and financial services".

From the procedural point of view, the term "fintech" refers to new applications, processes, products and business models in the financial services industry, which may consist of one or more complementary financial services that are provided from beginning to end through the Internet. The origin of the term can be traced back to the early 1990s, referring to the project "Financial Services Technology Consortium", initiated by Citigroup to intensify efforts in the direction of technological cooperation (Arner et al., 2015). However, in fact, the term "fintech" was already used in 1972 in a scientific paper devoted to models of analysis and solving of daily banking problems by VicePresident of the bank Manufacturers Hanover Trust (Bettinger, 1972).

\section{RESULTS}

Over the past ten years, the world has become actively involved in the emergence and spread of new currencies, technologies, business models and transaction forms in the wake of global economic shocks and the increasingly tight regulation of the financial industry. According to present knowledge, fintech as an area of innovation, start-ups and Internetization is rapidly gaining momentum. The number of fintech firms currently exceeds 12,000 worldwide.

Structure of fintech market can be displayed by types of corporate operations as follows:
1. Carrying out payment transactions - systems of mobile and electronic payments and transfers (PayPal, M-Pesa), currency exchange, use of crypto-currency as a means of payment, and so on. The group accounts for one third of all investments in the field of fintech. At the same time, the margin rarely reaches more than $2-3 \%$, therefore, it seems possible to earn only on the mass effect. An example is companies PayPal and Ant Financial (formerly known as Alipay), which carry out transactions of almost USD 100 billion a month and have succeeded due to close relationships with the world's largest trading platforms eBay and Alibaba.

2. Online intermediation, which allows users to accumulate funds for further investing (Cashing Out Offline) and accessing to shared products (Lending Club, Zopa). The segment concentrates almost $60 \%$ of the profits of modern banks and half of venture fintech investments. Most striking instance is the microfinance organization Wonga in the United Kingdom, which focuses on high-yield loans "till payday". Already in 2012, the company reached a mark of over USD 100 million net profit.

Platforms of online lending to small business have significantly developed, since banks often see too many risks in this. Big financial institutions, on the other hand, take the challenge of striving to take their niche in the online P2P business, collaborating with existing projects (JPMorgan and OnDeck), or by creating their own platforms (Goldman Sachs) profit (Solodkiy, 2017).

To ensure a high level of risk management, P2P platforms usually help investors when making a decision to finance a certain project. For example, in Europe, most platforms use the automatic choice, and in Australia, China, Italy and Korea, borrowers require to guarantee the reserve fund or charge a nominal fee of all funds raised. Crowdfunding companies (Kickstarter, CrowDo, Companisto) are also included in this group, in particular, donation-based, rewards-based crowdfunding platforms, and capital crowdfunding platforms. 
3. Data collection and analysis (Big Data). One example of the introduction of fintech in this segment is robo-advising, when selecting an investment portfolio is arranged by algorithms, offering the client an investment structure that corresponds to his investment preferences and risk profile, thereby reducing the annual maintenance costs from $1-2 \%$ common in the industry to $0.3-0.5 \%$ (Timko, 2016).

4. This group of financial management and private capital management includes technologies that help shape the credit rating based on non-standard information about the consumer (Neft, Lenddo), application of budgeting and saving of personal funds (TrueBill, Clinc, Qapital, Seedly), capital management startups, market analysis and investment platforms (Robinhood, Ellevest, DigFig), as well as price comparison platforms (Saving Plus, Habito, CompareAsiaGroup by Goldman Sachs).

5. Insurance as one of the most traditional and conservative industries. Fintech is implemented through $\mathrm{P} 2 \mathrm{C}$ insurance (PolicyBazaar, Trov), applications for rapid property evaluation (Cover), assistive technology for maximum fast and accurate calculation of insurance payments (BigML, the Floow), road safety improvement start-ups (Zendrive), cyber insurance, etc.

6. Creation of new software, process optimization of Back and Middle Offices, Support Services and accounting, BaaS-platforms and open API (YayPay, Copiny, FinReach, O2 Banking by Fidor Bank and Telefonica Germany).

Crypto-currencies in this context are already beginning to crowd out traditional money. For example, Estonia is planning to launch its own e-currency - estcoin (Korjus, 2017). All digital residents will be able to use this currency who are about 22,000 people from 138 countries today.

Practically complete absence of regulators stimulates the spread of crypto-currencies, although it increases the risk of fraud and manipulation. Besides bitcoins, whose capitalization remains the largest in the market, ethers (or ethereums) are fairly popular, whose cost is currently USD 238 , at the level of market capitalization at USD 22 billion.
The banking sector is becoming more dynamic, complex and versatile, including in consequence of the emergence of financial innovations, creating new opportunities for the implementation of the basic functions of the banking system. The role of financial innovations in increasing the competitiveness and efficiency of the functioning of the banking system as a guide of financial resources in the real sector of the economy is increasing. Partnership relations and integrated products, innovative hubs and labs, direct and venture capital investments, corporate and equity financing - worldwide banks have begun to use existing mechanisms to gain competitive advantages in the marketplace.

Among those who have already begun to invest in fintech, most are seeking strategic advantages for their main business, so the bulk of the funds is allocated to companies the product of which can be integrated into a bank line is used as a new digital channel to attract new customers, as well as one that can provide a better level of service and support. If recipients of the given funds are examined in more detail, the majority of transactions are focused on investments (online trading, robo-advisor management, property management, personal finance), online lending and blockchain. Directions of mobile money transfers and digital wallets or online banking are more restrained.

Bank BNY Mellon (Broom, 2015) has developed its own model of innovation development, which consists in the following steps:

1. Identification of opportunities. Through close cooperation with the fintech community, BNY Mellon has identified specific areas of interest that have the potential to improve existing technologies.

2. Protection of the idea. By working closely with fintech companies, BNY Mellon is exploring the possibility of using new technologies in a safe test environment.

3. Strategic review of options for investing.

4. Innovation centres. As part of BNY Mellon's aspiration to become a technology leader in the financial industry, the company creates 
innovative centres around the world that use new technologies to find new business approaches. The mission of the centres is to encourage a common, revolutionary thinking that will foster the development of talent and lead to innovation.

5. Fintech events. BNY Mellon organizes TechExpo in London to demonstrate diverse technological solutions and also actively collaborates with universities. These activities are aimed at encouraging creative thinking and aiming to help turn perspective ideas into a viable business through consulting and investment.

Bank of America is also looking for promising partnership relations, arranging annual Merrill Lynch Technology Innovation Summit, which aims to allow innovative entrepreneurs to meet with the team of the bank.

There are a number of models to adapt the innovations of fintech platforms by traditional banks. We will analyze which ones are reflected in the foreign financial markets.

1. Direct investment: Banks or entire holding companies in a number of countries provide equity financing for fintech platforms. In Japan, a holding company with a banking subsidiary has built a loan finance platform that provides its own funding. Some banks, in particular in the USA, provide debt finance to fintech companies or finance their loans directly as institutional investors through the purchase of loans or securitization.

2. Solving the problem of competition on the part of companies, which use the latest financial technologies for banks, can also be their merger. An example is an alliance between the largest bank holding JPMorgan Chase and online loan service OnDeck. JPMorgan refused to develop its own technology to suppress OnDeck, and at the same time did not wait until the start-up business grows to threatening sizes, instead they took the decision to come to a partnership compromise.

3. Acceleration and incubation as a form of cooperation between banks and fintech are very popular in Germany. Commerzbank Group, for example, manages several similar companies in the form of a main incubator and a garage start-up. Deutsche Bank is investing billions of euros in digital technology and expanding its network of innovative laboratories in London, Berlin and New York. Sparkassenverband is working on new solutions for alternative payment transactions, and Berliner Volksbank has opened its own venture capital company (Berliner Volksbank Ventures). Deutsche Bank, together with Commerzbank, joined the international consortium R3CEV for the development of midterm solutions for blockchain technology.

4. The implementation of the fintech banking concept. Key examples, which implemented similar ideas, include start-ups and financial companies like Bancorp, solarisBank and Basis, and banks such as BBVA, Citibank and Otkritie. Bancorp is the largest similar platform in the US, consisting of more than 100 non-bank financial service providers and operates USD 300 billion annually. solarisBank has a full banking license in Germany.

5. The development of own technological departments. According to Business Insider, 9,000 or about $30 \%$ of the 33,000 Goldman Sachs employees are engineers and programmers, which equals the total number of Facebook employees and even exceeds the Twitter or LinkedIn staff. The leaders of banks around the world have long been aware of the importance of technology. Celent estimates that global bank IT spending in 2015 reached nearly USD 200 billion and increase by about 5\% annually.

IT costs account for $10-15 \%$ of the bank's total expenses and the share is growing. IT expenditures in the financial sector are almost 10 times higher than the total amount of capital placed in the financial industry.

However, the problem for existing banks is that they are not very effective in managing large IT projects. More than $70 \%$ of IT costs are technical maintenance associated with the maintenance of outdated systems. Only about USD 50 billion in- 
vested in 2015 was aimed at developing new ideas Citi (2016). Instead, fintech companies are much more flexible in developing new products. Besides, they have no problems when integrating atrophied processes.

The introduction of new innovative developments can greatly simplify and accelerate the solution of many issues, achieving a result in a more efficient way. Banks are among the leaders in terms of the number of innovations introduced used by the general public. The technological innovations, initiated by banks, have a chance to find wide application, and also beyond the banking system. It is too early to talk about a threat to traditional banking in Ukraine, at least of fintech, because of insufficient number of successful developments in this area. Most of the projects that are developing today are based on international experience.

Let us consider the different phases of technology development in the Ukrainian banking system. At the first stage (1991-1995), the banking system was developed in the conditions of Ukraine's economic and political sovereignty. The developments at this stage include the adoption of the Law on Banks and Banking and the Concept of Electronic Money Transaction in Ukraine, the introduction of credit auctions on the American pattern for banks' access to NBU loans, the interest of international financial institutions, and the entry into the market of banking services of foreign representations banks. This period is characterized by high macroeconomic risks, the underdevelopment of the banking infrastructure, the imperfection of the organizational management structure and a low technological level of banking institutions and a lack of qualified banking personnel.

The second stage of innovative technologies (19962000) is determined by the monetary reform and adoption of the national currency. In 1998, for the first time, the Internet banking system was launched by PrivatBank in Ukraine, which meant creating one of the promising directions for the development of the national banking system.

The third stage (2001-2007) is associated with the expansion of business activities and a range of banking products and services. In addition, there was an active expansion of foreign banks that al- ready had sufficient innovative potential and pursued an aggressive policy that increased competition in the Ukrainian market. The growth of population welfare has led to the development of such a direction as retail banking. The increasing demand has allowed to expand the offer of innovative banking products, to introduce innovative processes for assessing credit and market risks, and so on. The majority of banks were actively engaged in the automation of activities, but the shortage of skilled personnel was noticeable.

The fourth stage of innovation in the banking system of Ukraine (2008-2013) is marked by the impact of the global financial crisis and the overcoming of its consequences. The increasing competition forced banks to implement meaningful innovations of the fintech industry for the first time. For example, $\mathrm{P} 2 \mathrm{P}$ lending, which is an alternative to traditional bank loans and deposits, provided access to cheap financial resources for small business development and economic stimulation.

At the fifth stage (from 2014 to the present time), the development of financial innovations is associated with the implementation of the Comprehensive Program for the Development of the Financial Sector of Ukraine until 2020 aimed at overcoming systemic problems in the financial sector and the Strategy for the Banking System Development by 2020.

To date, the integration of traditional and remote technologies is actively being implemented, the Internet and mobile banking are being implemented, aimed at preserving and expanding the client base, reducing transaction costs, reducing the complexity and cost of handling cash, the automatically controlling of operational risks, etc. Instead, reducing the profitability of the banking business requires a reduction in IT infrastructure costs.

According to a survey of representatives of the banking sector conducted by Mastercard in Ukraine, $58 \%$ of the polled bankers noted that their bank is ready for the introduction and active use of fintech, and $71 \%$ of bankers consider it promising to track innovations and buy readymade fintech solutions (Savenko, 2017). According to the results of the survey, Ukrainian banks are 
most interested in attracting fintech in the framework of analysis of large data and forecasting, remote banking, as well as digital wallets, payments and money transfers.

There is a remarkable practical implementation of the banks' intention to engage with fintech. For example, in 2015, FinTech Cluster was created by a Ukrainian venture hub, which involves merging banks, financial start-ups, and investment funds for the development of the Ukrainian fintech market. Its active participants include PrivatBank, Alfa-Bank, Raiffeisen Bank Aval and OTP Bank.

In late September 2017, the National Bank, OTP Bank and the non-profit incubator "1991 Open Data Incubator" launched another incubation program for fintech start-ups "Open banking lab" in partnership with MasterCard (Open Data Incubator, 2017a, 2017b). As part of the program, the banks provide third-party developers access to open (non-confidential) data and their own APIs. A test environment is created in which independent developers can test and enforce their authoring solutions. In addition, the bank allocates labor and financial resources in support of the program and provides remuneration for the winners. The authors of the best solutions for the project will receive a grant for development in sum of USD thousand.

We will outline the general tendencies of fintech development in Ukraine. First, banks remain the main investors who are ready to invest in the development of fintech. Moreover, at the banking level, there is a lack of separate budgets for innovation activities. These expenditures are mostly included in the budgets of several structural subdivisions. As of April 25, 2016, the following patents were registered for banking activities: 12 invention patents, 19 utility patents and 41 design patents (Hlibko, Yefremova, 2016).

Secondly, the Ukrainian market is characterized by a lack of understanding of the extent of fintech influence, the scale and directions of investments, the number of fintech companies and the variety of their ideas. Recently, the launch of the NBU project "Promotion of Fintech Development in Ukraine" was announced. The development priorities were selected as in digital e-banking, e- payments, digital lending (P2P, B2P and lending to financial companies), insurance (car insurance, travel insurance).

PrivatBank, First Ukrainian International Bank, Alfa-Bank (Ukraine) remain the leaders in the "Internet-banking" rating for several years in a row. In particular, in 2010, Privat 24 online bank was recognized as the winner of the "AWARDS Internet UA 2010" in the category "Internet payments" and "Best Internet Bank for B2C Customers".

It should be noted that the average annual growth of Internet banking clients, according to estimates of various Ukrainian banks, is 10-30\%. In 2014, PrivatBank had 12.6 million customers compared to 4.7 million in 2012 and 540,000 engaged customers in 2010. Alfa-Bank Ukraine increased the number of customers to almost 500,000 in 2014. However, while, within the retail segment, a minimum standard functionality has already formed, the lack of integrity and a systematic implementation of Internet banking for legal entities should be noted.

In the context of mobile banking, the leader is again PrivatBank, which offers a free service for devices running on Android and iOS, including the most popular app operations in Privat24. On average, the amount of mobile transactions per day is about UAH 1.5 million, and every tenth payment transaction is carried out through a smartphone. Mobile operators balance replenishment (76\%) and money transfers (12\%) are the most frequent operations. PrivatBank continues to improve technologically by introducing technology that allows owners of mobile devices with a builtin NFC chip to receive payments on contactless cards. In addition, the mobile version of Privat 24 has a unique functionality - accepting payments from a card through a POS terminal. The bank was the first in Eurasia to implement this service (Internet - acquiring, 2016).

It should be noted that to date, some services of PrivatBank are ahead of the market not only in Ukraine, but also in Europe. For example, cash withdrawal from an ATM without a card, international money transfer through the provision of access to your accounts by using a token, the 
ShareCreditCard service, as well as the mobile application MOSST Money Transfers (for the first time in Europe and the CIS, the face ID authentication mechanism is implemented). With the receiving of the general currency license of the NBU in September 2017, this service began to expand into foreign markets.

Sky Bank is planning to develop their remote banking system. They signed a cooperation agreement with the third largest fintech company in the world, Finastra (2016). The strategic replacement of the old systems by a solution by FusionBanking Essence will form a flexible and modern platform for improving the operational efficiency of the bank, enable it to sell innovative products faster and ultimately better serve its customers. Integrated capabilities will allow the bank to manage risk quickly, and the automatic processes will increase profitability.

Continuing the topic of introducing fintech innovations in Ukraine, the e-payment systems have to be mentioned. An example of the use of noncash Internet technologies is the financial innovation of PrivatBank "Online Collection", which was recognized as the best innovation in the rating "Innovation in Banking Technology Awards 2011" awarded by "The Banker" magazine. This new technology allows to solve the problem of cash transactions by adapting the simplest methods, in particular, keeping record for proceeds and their delivery, transfer to the bank. Today, this innovation is used by more than 2,000 Ukrainian companies.

For a long time, a constraining factor to the development of an electronic money system was the deficit of a regulatory framework. The first legal document aimed at settling the electronic payments process, which introduces European legislation, was the NBU Decree No. 178 dated June 25, 2008 , which secured the right to issue electronic money exclusively to banks and put forward the requirement to agree rules of work with the NBU within the electronic money system. The NBU Decree No. 481 dated November 04, 2010 was more significant. It was aimed at improving regulation and the monitoring of activities related to the issue and circulation of electronic money in Ukraine. The country's position regarding the regulation and functioning of the electronic payment market was determined in 2012 with the approval of the Law "On Amendments to Certain Legislative Acts of Ukraine (regarding the functioning of payment systems and the development of cashless payment)". The law has considerably expanded the conceptual base in the field of payment systems, the functions of the NBU, the maintenance of the register of payment systems, the supervision, the right to establish the order of operations and the maximum amount of electronic money (Pantelieva, 2012, pp. 417-419).

Currently the issuance of electronic money, according to the legislation of Ukraine, is to be carried out by 20 banks, 9 of which are members/participants of the National System of Mass Electronic Payments (NSMEP). The electronic money market in Ukraine is growing yearly. As of January 1, 2016 , the volume of issuance of electronic money increased to 30.692 million UAH, the total number of digital wallets was 40 million, of which 26.5 million are active, with the volume of transactions of $84,226 \mathrm{UAH}$ on average (National Bank of Ukraine, 2016).

According to the MasterCard study conducted in 2016, 72\% of Ukrainians are ready to pay for goods and services with the help of mobile banking. PrivatBank, the first of Ukrainian banks, launched a payment bot "My payments" in Facebook, which helps to pay utility bills directly in the social network messenger. Subsequently, a similar start-up function was launched in Kyiv named CoinyPay.

P2P lending is starting to develop in Ukraine. Among the platforms that are not connected with banks, first of all, "uCredit P2P Microlending Service" should be mentioned. Given the weak level of protection of the creditors' rights in Ukraine, the creators of the platform provide a wider range of services than standard foreign platforms offer. In addition to the analysis of borrowers' solvency and the organization of payments, they also implement the procedure of debt collection and judicial proceedings in case of occurrence of delay. Besides, secured P2P lending offered by Advance Finance Alliance may have a chance to succeed in Ukrainian circumstances. Within the banks, PrivatBank allows to take advantage of this fintech direction. In spring of 2016, it also launched 
the business financing service "KUB", implemented on the basis of $\mathrm{P} 2 \mathrm{~B}$ lending. At the moment, the service has financed projects with a sum totalling about UAH 1 billion.

The closeness of urban and rural administrations can be named the main problems of national fintech start-ups because of the unwillingness to perceive fintech solutions in the region. This has become one of the reasons that most innovative ideas are created with an eye toward a foreign market, where it is easier to find an investor. A major burden for development is also the lack of funding capital for implementing ideas, the culture of venture funds, the potential for selling innovative solutions or the ability to secure a business. A separate issue is cybersecurity, especially after hacking into Ukrainian financial institutions, blocking the websites of the Ministry of Finance and the State Treasury Service in June and December 2016, as well as the latest cyberattack on June 27, 2017.

Mobile operators and trading networks could become a threat to traditional banks in the Ukrainian market. However, the trust and positive experience when using fintech-based Internet shops has not wrestled down the need for banking institutions so far.
A more real danger for Ukrainian banks is represented by international institutions, which obtain new principles in the core of their activities, bringing most of the services from ATMs and offices to the screen of the smartphone.

The regulation of the NBU somewhat limits the possibilities for the introduction of financial services in Ukraine. All non-banking institutions are forced to open accounts, which does not let financial companies be independent from banks.

Although the PrivatBank's P2P lending initiative, a similar service from AFA, the project of mobile money from Kyivstar, the Monobank's mobile banking project have not had a significant success in the consumer market yet, they demonstrate a frank desire of the Ukrainian business to develop in the direction of fintech. It can be stated that the national banking system does not stand aside from the global innovation process in the banking sector and has sufficient potential for the active introduction of financial innovations that have shown themselves positively in the markets of other countries. However, the general processes of digitization of the economy need to be accelerated; otherwise, opportunities may become threats for Ukraine.

\section{DISCUSSION AND CONCLUSION}

Over the past ten years, the world has become actively involved in the emergence and spread of new currencies, technologies, business models and transaction forms in the wake of global economic shocks and the increasingly tight regulation of the financial industry. According to present knowledge, fintech as an area of innovation, start-ups and Internetization is rapidly gaining momentum. The number of fintech firms currently exceeds 12,000 worldwide.

The term fintech is used in various business contexts, often in inconsistent and ambiguous way. For a long time there were no attempts to find out the consensual meaning of this notion. However, the term itself was used already in 1972. The definitions of financial technologies as a result of the analysis were divided into several groups, depending on the object, which fintech is associated with. Nonetheless, due to the impossibility of reaching consensus in obtaining a unified definition by expert analysis, due to the diverse nature of the phenomenon under study, it was considered more efficient to use the classification as a way of facilitating the perception of a general definition and the definition of relations between certain types of fintech.

Fintech products have been classified by market segments, and the fintech market structure has been differentiated by the types of companies' activities. In addition, the study considered the division of financial technologies into the respective fields and groups in accordance with the views of the recognized experts of the international financial market. The study described the transactional and intertemporal models of fintech. 
Thus, it is proposed to define "fintech" as a multi-vector, unique and comprehensive form of mutual influence of the newest technologies on the financial industry, which is characterized by quantitative and qualitative development through start-ups and increase of efficiency of service delivery.

The growing fintech competition is a challenge for banks - according to McKinsey calculations, they can lose about $29-35 \%$ of revenue in favor of new players. Instead, in recent years, the fintech representatives' tendency to cooperate with traditional institutions is growing in order to create a synergetic effect and increase the mutual benefits in favor of higher quality and efficiency of services to clients. In our turn, we have summarized the forms that such cooperation takes: incubators, acquisitions, partnerships, the creation of venture funds, fintech departments or subsidiaries, a mixed form, fintech (neo) bank, remote bank.

The development of fintech start-ups in Ukraine faces a number of obstacles, but banks, due to a number of objective reasons, are not able to increase the efficiency of their activities on their own. It is such a controversy that leads to the need for their cooperation and the definition of common areas of development.

One of the potential areas for financial support may be the involvement of banks in the development of fintech ideas at the stage of conception and testing, as well as the creation of innovative financial hubs.

By developing a particular form of cooperation with a fintech company, the bank may commit a number of mistakes described by the author, but they can be prevented following the outlined principles for the introduction of financial innovations to banks (implementation, efficiency, value propositions, etc.).

A promising area of research may be the question of the right of fintech companies to open accounts for clients - individuals and legal entities, that is, to carry out genuine banking operations under the control and regulation of the National Bank and payment insurance in any stable organization. Such measures would lead to a bigger number of financial institutions in the market that would compete with each other, increasing the quality and reducing the cost of their cashless services.

Thus, it can be concluded that the development of cooperation between traditional banking institutions and the fintech industry representatives in the long run can increase the level of customer service to a higher, more efficient and productive level. Such an alliance will be beneficial for the state and in the context of general social well-being, as its activities will directly or indirectly address the problems of financial literacy and living standards.

\section{REFERENCES}

1. Arner, D. W. (2015). The Evolution of Fintech: A New Post-Crisis Paradigm? In D. W. Arner, J. N. Barberis \& R. P. Buckley (Eds.), The University of Hong Kong (pp. 1-49). Retrieved from http://hub. hku.hk/handle/10722/221450

2. Bettinger, A. (1972). Fintech: A Series of 40 Time Shared Models Used at Manufacturers Hanover Trust Company. Interfaces, 2(4), 62-63.

3. Broom, D. (2015). Innovation in Payments: The Future is Fintech. Retrieved from www.bnymellon.com
4. Citi (2016). Digital Disruption. How Fintech is Forcing Banking to a Tipping Point. Retrieved from www.nist.gov

5. Finastra (2016). FusionBanking Essence. Retrieved from www. finastra.com

6. Hlibko, S. V., Yefremova, K. V. (2016). Правове регулювання відносин у мережі інтернет: монограбія [Pravove rehuliuvannia vidnosyn u merezhi internet: monohrafiia]. Kharkiv: Pravo. Retrieved from www.ndipzir.org.ua
7. Internet - acquiring (2016). Retrieved from www.galileo.com.ua

8. Korjus, K. (2017). Estonia could offer 'estcoins' to e-residents. Retrieved from www.medium.com

9. National Bank of Ukraine (2016). Electronic money. Retrieved from www.bank.gov.ua

10. Open Data Incubator (2017a, 2017b). Retrieved from www.1991.vc

11. Pantelieva, N. A. (2012). New stage in the development of the electronic payment market. 
Collection of scientific papers of the international scientific and practical conference. Kiev: KNEU.

12. Savenko, S. (2017). FinTech-cmapтапы в Украине. Когда ждать «зеленый свет»? [FinTech-startapy $v$ Ukraine. Kogda zhdat "zelenyy svet"?]. Retrieved from www.news. finance.ua
13. Schueffel, P. (2016). Taming the Beast: A Scientific Definition of Fintech. Journal of Innovation Management, 4(4), 32-55. Retrieved from http://www.open-jim. org/article/view/322/221

14. Solodkiy, V. (2017). С миру nо нитке: как из коллективных инвестиций рождается бизнес [S miru po nitke: kaki iz kollek- tivnykh investistiy rozhdaetsya biznes]. Retrieved from www. forbes.ru

15. Timko, E. (2016). Финансовый муравейник: что представляет собой финтехиндустрия [Finansovyy muraveynik: chto predstavyaet soboy fintekh-industriya]. Retrieved from www.forbes.ru 